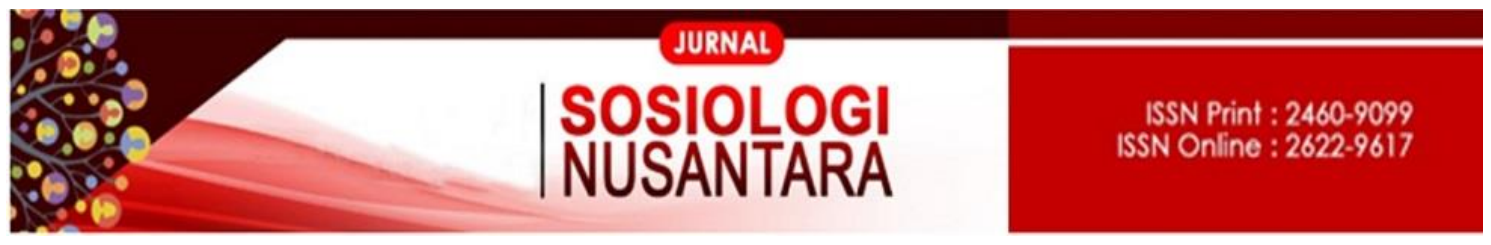

https://ejournal.unib.ac.id/index.php/jsn

DOI ://doi.org/10.33369/jsn.5.1.77-90

\title{
KEKERASAN DALAM DUNIA PENDIDIKAN: TINJAUAN SOSIOLOGI PENDIDIKAN
}

\author{
Violence In The World of Education (A Sociology of Education Review)
}

\author{
Dasma Alfriani Damanik \\ dasma_alfriani@yahoo.com
}

Fakultas Ilmu Sosial dan Ilmu Politik, Universitas Nusa Cendana, Kupang

\begin{abstract}
Abstrak
Kenakalan pelajar di Indonesia tidak terlepas dari pengaruh pola relasi subjek - objek yang terbangun dalam ilmu pengetahuan.Pola relasi tersebut berakar pada ketidakobjektivan sistem pendidikan, yaitu mengenai prinsip, tujuan, organisasi sosial, kurikulum, metode mengajar, evaluasi, peserta didik, pendidik, fasilitas dan pembiayaan.Kehancuran dalam dunia pendidikan terjadi bukan karena nilai akademik memburuk namun karena moral yang hancur.Keluarga dan kehidupannya tidak boleh disepelekan dan diabaikan. Padahal kecenderungan sekarang akibat kebutuhan material yang kian memuncak, banyak ibu dan bapak yang bekeja dan menyerahkan masalah hidup anaknya kepada asisten rumah tangga atau "orang bayaran" sehingga hampir segala urusan pendidikan sepenuhnya diandalkan kepada sekolah dan celakanya di sekolah masalah afektual, nilai moral hampir-hampir tidak tersentuh.Pengaruh teknologi seperti tayangan-tayangan yang ada di televisi yang jauh dari norma-norma agama akan ditiru oleh para pelajar sehingga membawa perubahan pada perilaku menyimpang berupa kenakalan yang dilakukan pelajar terhadap gurunya. Kenakalan pelajar merupakan perilaku menyimpang yang dilakukan pelajar, seperti mem-bully guru. Teori kontrol oleh Hirski menyatakan bahwa penyimpangan dan bahkan kriminalitas atau pelaku kriminal merupakan bukti kegagalan kelompok-kelompok sosial konvensional seperti keluarga, sekolah atau kelompok-kelompok dominan lainnya dalam mengikat individu agar tetap conform. Untuk itu diperlukan kontrol/pengendalian dari keluarga yaitu orang tua, pihak sekolah dan komunitas ekstrakulikuler, sehingga kenakalan pelajar tidak terjadi lagi dalam dunia pendidikan.
\end{abstract}

Kata Kunci: Sistem Pendidikan, Kenakalan Pelajar, Kontrol / pengendalian

\section{Abstract}

Student delinquency is inseparable from the influence of the subject - object relationship pattern that is built in science. The pattern of relations is rooted in the case of the objectivity of the education system in Indonesia, namely the principles, objektives, social organization, curriculum, teaching methods, evaluation, student, educators, facilities and financing. Destruction in the world of education occurs because academic values deteriorate but because of moral collapse. Family and life must not be 
underestimated and ignored. Current trends due to material requirements are mounting, many parents submit their childrens's life problem to household assistants so that all matters of education are relied on the school and in school moral values are not touched. The influence of technology such as television shows far from religious norms will be imitated by students so as to bring a change to deviant behavior namely student misbehavior towards the teacher. Student delinquency is a deviant behavior where students commit acts of violence such as bullying the teacher. The theory of control by the Hirski that deviations and even crime are evidence of the failure of conventional social groups to bind individuals will remain confusing like family, school or other dominant groups. For that we need a control or control from the family, namely parent, the school and the extracurricular community so that student delinquency does not occur in the world of education.

Keywords: education system, Student delinquency, control

\section{PENDAHULUAN}

Komisi Perlindungan Anak Indonesia (KPAI)berkoordinasi dengan Kadisdik Provinsi Jawa Tengah Gatot Bambang Hastowo terkait video viral guru di-bully murid di Kendal, pada hari Sabtu tanggal 10 November 2018. Hasil pertemuan itu, para murid diminta tidak mengulangi perbuatan mereka kembali dari informasi yang diterima KPAI, pihak sekolah sudah memanggil dan membina para siswa yang terlibat dalam video yang viral tersebut pada Sabtu 10 November 2018. Para siswa tersebut juga diminta menuliskan pernyataan tidak akan mengulangi guyonan seperti dalam video yang viral tersebut. Selanjutnya pada Senin 12 November 2018 giliran para orang tua siswa tersebut yang dipanggil pihak sekolah dan membuat komitmen bersama untuk menasehati anak-anaknya agar tidak mengulangi lagi perbuatannya dan dapat lebih menghormati para gurunya," kata komisioner KPAI Retno Listyarti dalam keterangan tertulis pada hari Senin, tanggal 12 November 2018.Pertemuan itu dihadiri Kepala SMK NU 3 Kaliwungu, Muhaidin, sejumlah guru, pengawas sekolah, siswa, dan para orang tua murid serta Bupati Kendal Mirna Annisa.KPAI mengapresiasi Disdik Jateng yang dengan cepat menangani kasus video viral tersebut dan melaporkan perkembangan kepada Gubernur Jateng Ganjar Pranowo dan KPAI.Retno mengatakan bahwa pihak sekolah dan guru Joko Susilo mengakui perbuatan yang terekam video viral tersebut hanya bercanda, bukan kekerasan.Namun pihak sekolah menilai candaan tersebut sudah melampaui batas.Pihak sekolah dan guru yang bersangkutan menyatakan bahwa yang terekam di video yang viral tersebut hanya guyonan, bukan kekerasan atau pengeroyokan.Namun pihak sekolah mengakui guyonan atau candaan sejumlah siswa 
terhadap gurunya merupakan tindakan atau perbuatan yang kelewat batas kesopanan/etikasosial (Hidayat, Selasa 13 November 2018).

Perilaku kasar dari siswa terhadap guru lagi-lagi terjadi, kali ini di Jakarta.Sebuah video viral memperlihatkan seorang guru yang sedang mengajar di kelas kemudian ada suara siswa mengucapkan kata-kata kasar yang tidak pantas.Siswa tersebut akhirnya mundur (dikeluarkan) dari sekolah.Peristiwa ini terjadi di SMA AlAzhar Kelapa Gading, Jakarta Utara.Kepala sekolah, Sumanto, mengatakan bahwa pihaknya menyayangkan peristiwa ini. Kemudian kepala sekolah tersebut bahwa dirinya sudah meminta penjelasan dan klarifikasi kepada guru dalam video tersebut dan guru tidak menyadari pada saat proses belajar kelompok di kelas yang kondusif itu ada salah seorang siswa yang merekam," kata Sumanto di SMA Al-Azhar Kelapa Gading, Jalan Bulevard Timur, Pegangsaan Dua, Jakarta Utara, Jumat (1/3/2019).Peristiwa itu terjadi pada 19 Februari 2019 lalu. Sekitar sepekan kemudian, pihak sekolah yang mengetahui video itu kemudian memanggil orangtua dan siswa yang bersangkutan.Siswa itu mengaku merekam video saat di kelas lalu men-dubbing suaranya.

"Siswa meyakini dan mengakui bahwa video itu diambil pada siang hari tanggal 19 (Februari) dan itu hari Selasa jam 14.00 WIB dan kemudian malam harinya isengiseng dibuka dan kemudian dia memasukkan suara dubbing dan dengan iseng juga dia mengupload ke Instagram pribadinya," jelas Sumanto. Sumanto mengatakan baik guru maupun siswa lain di kelas tidak mendengarkan kata-kata kasar seperti yang terucap di video itu. Guru itu juga tidak sadar direkam (Rahayu - detikNews, Jumat 01 Maret 2019).

Kasus kematian guru honorer mata pelajaran seni rupa di Sampang, Madura, Jawa Timur, akibat pemukulan terhadapnya oleh seorang murid, menambah deretan masalah dalam sistem pendidikan nasional, khususnya pendidikan dasar dan menengah. Inilah ironi dalam dunia pendidikan Indonesia, karena banyak sekali penyimpanganpenyimpangan dalam dunia pendidikan.Kekerasan yang terjadi dalam dunia pendidikan, baik dari guru terhadap murid, murid terhadap guru, dan sesama murid, tidak terlepas dari pengaruh pola relasi subjek-objek yang terbangun dalam ilmu pengetahuan. Pola relasi tersebut berakar pada perkara objektivitas ilmu pengetahuan. Sistem pendidikan di Indonesia tidak objektif, ini terdapat pada kelemahan sistem pendidikan nasional dewasa ini seperti: masalah prinsip (Pandangan pendidikan bersifat microscopis 
pendidikan dipandang sebagai dunia tersendiri yang terpisah dan terpencil dari aspekaspek, pendidikan kurang mempunyai sangkut paut dengan pembangunan sehingga menghasilkan tamatan sekolah menengah yang serba canggung sarjana-sarjana ngangur dan sebaginya, lebih memenuhi keinginan subyektif masyaakat akan pendidikan, tidak adanya keseimbangan horizontal dan vertikal, ada tembok pemisah antara sekolah dan masyarakat, program dan pelaksanaan pendidkan terbatas oleh usia sekolah atau sekolah age), masalah tujuan (pembentukan manusia pancasila sebagai tujuan pendidikan nasional kurang dijabarkan secara terperinci, memperkembangkan anak didik tidak sebagai suatu totalitas maksudnya hanya mementingkan dimensi horizontal saja atau hanya dimensi vertikal saja, tujuan kurikulum hanya hanya menitikberatkan kepada guru.

Sehingga bila guru mengajarkan bahan pelajaran menanggap tugasnya telah selesai, pembentukan jiwa yang intelektualistis terlalu mengungkapkan ratio melupakan aspek-aspek kepribadian yang lain, pembentukan jiwa yang priyayi, bekerja di belakang meja yang teoritis bekerja menurut perintah, sejak awal anak didik untuk bersikap individualism akan sistem pendidikan konvensional menghasilkan anak yang berjiwa individualis pula), Organisasi social (Hanya menyelenggarakan pendidikan formal, penjenjangan sekolah $6-3-3$ yaitu SD 6 tahun, SMP3 tahun, SMA 3 tahun, antara SD dan SMP merupakan dua jenjang yang terputus terdapat jarak pemisah, pada SMU terdapat jurusan IPA, IPS dan Bahasa, Pada SMU menggunakan sistem 1 tahun ajaran dan sistem kenaikan kelas), kurikulum(Kurikulum menitikberatkan kepada standar umum dan kemampuan rata-rata anak didik, kurikulum berdasarkan subjek mattercenteredyaitu berpusat pada mata pelajaran, belajar dibatasi oleh dinding kelas dan halaman sekolah, pendekatan kurikulum lebih terikat pada textbooks yaitu menhapalkan rumus-rumus dan tahun-tahun sejarah serta kurang memberikan pengalaman hidup yang nyata pada anak didik), metode mengajar(metode mengajar lebih berpusat kepada guru dan bahan pelajaran sehingga proses mengajar terpisah dari proses belajar, metode mengajar verbalitas-intelektualitas mengutamakan pemberian ilmu sebanyak-banyaknya secara teoritis dan steril dari dunia kerja dan jiwa makarnya), evaluasi (sistem evaluasi hanya menitikberatkan kepada penilaian terhadap kemampuan intelektual (pengetahuan dan kecerdasan) tidak meliputi sasaran-sasaran pendidikan lainnya, anak didik dirangsang untuk mengutamakan pengejaran ijazah yang dianggap 
sebagai kunci untuk memasuki dunia kerja ataupun pendidikan lainnya), anak didik (dalam proses pendidikan anak didik sering dipandang sebagai obyek belaka, kenyataan sering menunjukkan bahwa kesempatan pendidikan lebih banyak diperoleh bagi anak didik yang berasal dari lapisan masyarakat yang mampu/kerja, sekolah lebih menitikberatkan pada sistem klasikal di mana guru menganggap dan memperlakukan semua anak didik sama baik mengenai background maupun kediriannya sehingga anak yang cepat belajar dihambat oleh yang lambat dan yang lambat belajarnya harus mengejar yang cepat, kondisi struktur pengorganisasian sekolah mengakibatkan banyaknya drop out kalangan pelajar maupun mahasiswa di Indonesia), pendidik(guru lebih banyak hanya berfungsi dan bertugas sebagai pengajar di sekolah, guru cukup mengajar sesuai dengan textbooks secara teoritis verbalistis, kebanyakan dengan menggunakan metode ceramah, secara tradisional guru ditempatkan dan dituntut sebagai orang yang harus selalu paling tahu tentang mata pelajarannya disbanding dengan murid-murid), fasilitas(ruang dan peralatan yang disediakan lebih banyak digunakan untuk pengajaran akademis), pembiayaan (pembiayaan mengharapkan sebagaian besar disediakan oleh pemerintah pusat).

Objektivitas yang sangat ditekankan dalam ilmu pengetahuan dan proses pendidikan berpengaruh pula terhadap terbentuknya paradigma dan mentalitas subjekobjek. Paradigma dan mentalitas tersebut dapat teraplikasi dalam relasi gurumurid. Guru dapat memandang murid sebagai objek, yang kepadanya harus diisi dengan berbagai informasi dan pengetahuan. Murid juga menempatkan dirinya sebagai wadah kosong yang mau tidak mau, harus menerima isi pelajaran (Alexander Aur, 2018).

Demikian pula murid akan memandang guru sebagai objek, yang kepadanya murid dapat mengarahkan segala penilaian yang buruk karena dianggap sebagai penyebab kegagalannya dalam belajar dan persoalan-persoalan lain terkait proses pembelajaran yang dialami murid. Guru mengajar tidak jelas di mana rendahnya kompetensi paedagogik guru terutama dalam penguasaan kelas serta upaya penciptaan suasana belajar yang kreatif dan menyenangkan dan menantang kreativitas serta minat siswa (Retno Listyarti dalam Hidayat, 2018). 


\section{METODE PENELITIAN}

Tujuan dalam tulisan ini adalah untuk mendeskripsikan dan menganalisa dengan menggunakan kajian sosiologi pendidikan mengenai masalah sosial dalam hal ini kenakalan pelajar yaitu kekerasan dalam dunia pendidikan.Metode yang digunakan dalam tulisan ini adalah metode studi kasus yaitu metode dalam rangka mengeksplorasi masalah sosial secara terbatas namun mendalam.

\section{PEMBAHASAN}

Kekerasan yang terjadi dalam dunia pendidikan, baik dari guru terhadap murid, murid terhadap guru, dan sesama murid, tidak terlepas dari pengaruh pola relasi subjekobjek yang terbangun dalam ilmu pengetahuan.Pola relasi yang demikian berakar pada perkara objektivitas ilmu pengetahuan.Materi pelajaran berciri ilmu pengetahuan dan menekankan kecakapan intelektual.Dengan ciri dan penekanannya yang demikian, pembelajaran terhadap materi pelajaran, menuntut guru dan murid bersikap objektif terhadap isi materi pelajaran.Dengan demikian, ciri ilmiah dari materi pelajaran merupakan hal yang paling utama dalam mempelajari materi pelajaran. Karena isi materi pelajaran menekankan ciri ilmiah, maka proses pembelajaran materi pelajaran merupakan proses transfer ilmu pengetahuan dari guru kepada murid. Dalam proses yang demikian, sedapat mungkin emosi dan sikap batin murid dan guru tidak memengaruhi kadar objektivitas ilmu pengetahuan.

Objektivitas yang ditekankan dalam ilmu pengetahuan bersumber dari metode kerja ilmu-ilmu alam.Objek kajian ilmu-ilmu alam adalah alam yang bersifat material.Ilmu-ilmu alam seperti kimia, fisika, biologi menghadapi alam semata-mata sebagai objek material dan empirik. Dalam mengkaji alam, ilmu-ilmu alam tidak boleh bersikap subjektif dan emotif terhadap objek kajiannya.Sikap yang digunakan hanyalah sikap objektif.Itulah sikap ilmiah ilmu pengetahuan.Metode kerja dan sikap ilmiah dalam ilmu alam itu berlaku juga untuk ilmu-ilmu sosial seperti ilmu politik, ilmu sejarah, ilmu hukum, sosiologi, dan antropologi.Objek ilmu-ilmu sosial yakni manusia dan kehidupannya disikapi sedemikian rupa seperti objek alam yang bersifat material.Meskipun pada manusia terdapat aspek-aspek subjektif seperti emosi dan suasana batinnya, tetapi aspek subjektif itu disikapi sebagai fakta objektif yang sejajar dengan fakta objektif dalam alam.Objektivitas yang sangat ditekankan dalam ilmu 
pengetahuan dan proses pendidikan berpengaruh pula terhadap terbentuknya paradigma dan mentalitas subjek-objek. Paradigma dan mentalitas tersebut dapat teraplikasi dalam relasi guru-murid. Guru dapat memandang murid sebagai objek, yang kepadanya harus diisi dengan berbagai informasi dan pengetahuan. Murid juga menempatkan dirinya sebagai wadah kosong yang mau tidak mau, harus menerima isi pelajaran. Demikian pula murid akan memandang guru sebagai objek, yang kepadanya murid dapat mengarahkan segala penilaian yang buruk karena dianggap sebagai penyebab kegagalannya dalam belajar dan persoalan-persoalan lain terkait proses pembelajaran yang dialami murid. Guru mengajar tidak jelas.Guru memberi pekerjaan rumah terlalu banyak. Pernyataan-pernyataan seperti itu sering kali diungkapkan oleh murid terhadap gurunya.Kasus-kasus yang terjadi dalam dunia pendidikan, seperti kasus pemukulan terhadap guru oleh murid, pemukulan murid oleh guru, dan perkelahian antarmurid, merupakan dampak dari relasi subjek-objek antara guru dan murid, serta murid dan murid.Relasi subjek-objek yang terbangun secara diam-diam melalui metode kerja ilmu pengetahuan.Jika objektivitas ilmu pengetahuan adalah hal penting dalam proses pembelajaran, lalu bagaimana cara mengasah emosi dan batin murid dengan nilai-nilai moral? Sungguh benar bahwa nilai-nilai moral -seperti keadilan, kejujuran, hormat kepada sesama manusia, hormat kepada kehidupan dan sebagainya bersifat objektif dan berlaku universal tetapi pengolahan dan internalisasi (penghayatan) bersifat subjektif.Dengan demikian, bukankah tetap berlangsung relasi subjek-objek?Sudah banyak usaha dari para pihak dalam dunia pendidikan, misalnya Kementerian Pendidikan dan Kebudayaan, untuk mengakhiri relasi subjek-objek.Usaha itu terwujud dalam perubahan dan pergantian isi kurikulum.Dalam kurikulum dimasukkan pula nilainilai moral.Tujuannya adalah guru juga membentuk karakter agar siswa menjadi beradab.Nilai-nilai moral disisipkan dalam materi pelajaran dan disampaikan kepada murid selama proses pembelajaran.

Dengan demikian, kepekaan rasa dan batin murid terasah. Kepedulian sosial, penghormatan terhadap sesama dan lingkungan hidup terbangun dalam diri murid.Usaha dan tujuan tersebut sungguh baik dan benar tetapi usaha dan tujuan itu selalu dibayang-bayangi oleh tuntutan objektivitas dari ilmu pengetahuan.Alih-alih melampaui relasi subjek-objek, justru yang terjadi adalah tetap terjaga dan terawat relasi yang demikian.Mengapa?Karena dengan memasukkan nilai-nilai moral dalam setiap 
mata pelajaran, justru membuat guru memperlakukan murid sebagai objek yang harus menerima nilai-nilai moral yang diberikannya.Secara objektif, murid adalah orang yang harus menerima nilai-nilai moral yang ditanamkan melalui pembelajaran ilmu pengetahuan. Dengan demikian, cita-cita mengakhiri relasi subjek-objek dengan cara menanamkan nilai-nilai moral melalui pembelajaran materi-materi pelajaran, justru menempatkan murid sebagai objek penanaman nilai-nilai moral. Internalisasi nilai-nilai moral oleh siswa tidak berlangsung secara baik karena murid tetap berada pada posisi sebagai objek. Proses pendidikan, khususnya pada level pendidikan dasar dan menengah, tidak semata-mata bertujuan mentransfer ilmu pengetahuan. Lebih dari itu, proses pendidikan pada level tersebut juga membentuk karakter beradab dalam diri murid.

Meski demikian, bukan berarti menempatkan murid sebagai objek yang harus menerima nilai-nilai moral, menginternalisasikannya, supaya terbentuk karakter beradabnya.Murid bukan objek pendidikan. Murid bukan objek transfer ilmu pengetahuan oleh guru. Murid juga bukan objek penanaman nilai-nilai moral.Murid bukan objek pembentukan karakter beradab.Sebaliknya murid adalah subjek pendidikan.Sebagaimana guru adalah subjek dalam pendidikan, demikian pula murid adalah subjek pendidikan. Guru dan murid sama-sama menyandang eksistensi sebagai subjek dalam proses pendidikan.

Kepemilikan dan penguasaan ilmu pengetahuan oleh guru, tidak berarti menjadikan hanya guru sebagai subjek.Meskipun murid belum menguasai dan memiliki pengetahuan yang banyak, tetapi murid adalah subjek. Dalam proses pendidikan, guru dan murid berada pada posisi yang setara, yakni sebagai subjek pendidikan. Posisi setara itu terbangun melalui usaha menjalin relasi subjek-subjek antara guru dan murid. Relasi yang demikian dimulai sejak setiap orang yang terlibat dalam proses pendidikan menyatakan dirinya sebagai pendidik. Sebagai pendidik, mereka menganut paradigma pendidikan yang tepat. Para pihak yang terlibat dalam proses pendidikan, baik guru, murid, orang tua murid, karyawan sekolah, penjaga sekolah, petugas keamanan sekolah, pengantar sekolah, maupun pengambil kebijakan dalam bidang pendidikan menyatakan bahwa dirinya (mereka semua) adalah pendidik. Dengan demikian, setiap tutur kata dan tindakannya merupakan ungkapan keberadaannya sebagai pendidik. Sebagai pendidik, mereka menganut paradigma bahwa proses pendidikan dan proses belajar mengajar 
merupakan suatu hubungan antar-manusia yang sangat kompleks. Mereka semua terlibat sebagai pendidik dalam hubungan yang demikian. Bagi mereka, tujuan proses pembelajaran dan proses pendidikan adalah perubahan dan per tumbuhan dalam diri murid. Para murid berubah dan tumbuh sebagai manusia yang utuh. Sebagai manusia dan sebagai subjek, para murid berubah, tumbuh, dan berkembang secara utuh, meliputi semua aspek dirinya: tubuh, kognitif, emosi, suasana batin, dan tindakannya. Paradigma pendidikan yang demikian, terwujud dalam memperlakukan murid sebagai subjek.Ketika di dalam kelas, saat mengajar mata pelajaran apapun, guru memperlakukan murid sebagai manusia muda yang sedang berproses mematangkan segala aspek dalam dirinya.Setiap murid sudah pasti memiliki kemampuan yang berbeda-beda.

Ada yang lambat dalam berproses, ada pula yang cepat dalam proses tetapi kelambatan dan kecepatan dalam proses, sama sekali tidak mengubah status antropologis diri murid, yakni manusia muda yang sedang berproses mematangkan segala aspek dalam dirinya. Dengan menempatkan murid sebagai manusia muda sedang mematangkan dirinya, murid pun akan disapa dan diperlakukan oleh semua pendidik sebagai subjek pendidikan. Murid dimanusiawikan dalam proses pendidikan dan pembelajaran. Itulah hakikat dari relasi subjek-subjek antara pendidik dan murid dalam proses pembelajaran dan pendidikan.Relasi subjek-subjek dapat dipraktikkan dalam setiap pembelajaran materi pelajaran.Meskipun ilmu pengetahuan menekankan objektivitas, tetapi objekvititas dan sikap ilmiah tidak menjerembabkan guru-murid dalam relasi subjek-objek karena relasi subjek-subjek terbangun secara baik. Relasi subjek-subjek bertumpu pada kodrat yang sama dari guru dan murid, yakni sebagai manusia.

Selain relasi subjek-subjek dapat dipraktekan dalam setiap pembelajaran materi pelajaran, pendidikan moral sangat penting dalam dunia pendidikan.Pendidikan moral adalah pendidikan yang bukan mengajarkan tentang akademik, namun non akademik khususnya tentang sikap dan bagaimana perilaku sehari-hari yang baik. Pendidikan moral sudah dikalahkan oleh pendidikan yang lain seperti matematika, IPA, IPS dan lainnya. Waktu di sekolah habis untuk mengejar nilai akademik.

Murid-murid dipaksa belajar agar nilainya pada saat ujian nanti membaik dan bisa mengharumkan nama di mana dia bersekolah. Guru, pelajar, dan pemerintah 
seakan-akan lupa ada pelajaran yang lebih penting dari itu semua yaitu pendidikan moral. Pendidikan yang akan dibawa sampai akhir hayat, pendidikan yang akan menentukan bagaimana dia dipandang masyarakat lain kelak, pendidikan yang membuat dia menjadi manusia yang berguna, pendidikan yang akan membawa akan di surga atau neraka siswa siswinya kelak. Dari kalimat tersebut dapat diketahui bahwa kehacuran dalam dunia pendidikan terjadi karena nilai akademik memburuk namun karena moral yang hancur.

Pendidikan nilai merupakan suatu upaya pembelajaran kepada peserta didik, untuk memahami dan mengenal, menanamkan dan melestarikan, menyerap dan merealisasikan nilai-nilai luhur dalam kehidupan manusia, yang berhubungan dengan kebenaran, kebaikan dan keindahan dalam pembiasaan bertindak yang konsisten dengan tuntutan nilai.Keluarga sebagai lingkungan yang pertama membentuk sifat, watak dan tabiat manusia, sudah sepantasnyalah memiliki peranan yang sangat besar dalam pelaksanaan pendidikan nilai terhadap anak. Orang tua memiliki tanggung jawab bagaimana anak diarahkan pada hal-hal yang baik dan buruk sesuai dengan nilai-nilai norma masyarakat sebagai lingkungan tempat tinggal (Tata Abdulah dalam Cahyadi: 2019). Sementara ini, kenyataan di masyarakat banyak peranan orang tua diserahkan dalam mendidik anak-anaknya ke orang lain atau para asisten rumah tangga, sudah barang tentu anak-anak tersebut memiliki sifat atau tabiat yang akan jauh berbeda dengan tabiat orang tuanya dan anak akan cenderung menginkuti apa yang ia lihat, yang menyenangkan dirinya tanpa disadari oleh baik buruk, benar salah, wajar tidak wajar, pantas tidak pantas, boleh tidak, semua itu akan dilabraknya (Tata Abdulah, dalam Cahyadi : 2019). Hal ini sejalan dengan pendapat Kokasih Djahiri (dalam Cahyadi, 2019):

Keluarga dan kehidupannya tidak boleh disepelekan dan diabaikan.Padahal kecenderungan sekarang akibat kebutuhan materiil yang kian memuncak banyak ibu dan bapak bekerja dan menyerahkan masalah hidup anaknya kepada "orang bayaran" (asisten rumah tangga), sehingga hampir segala urusan pendidikan sepenuhnya diandalkan kepada sekolah dan celakanya di sekolah masalah afektual, nilai moral hamper-hampir tidak tersentuh.

Apabila kita mencermati tayangan-tayangan televisi, jarang sekali program acara yang mengajak atau memberikan gambaran tentang anak sholeh, adat sopan santun, nilai-nilai luhur bangsa.Saat ini tayangan televisi hampir semuanya mengarah kepada jenis hiburan yang sangat fulgar atau cerita selebriti yang seronok dan jauh dari norma- 
norma agama, sedangkan itu semua suka dijadikan idola oleh para remaja. Wajar apabila sekarang ini nilai moral dan norma anak bangsa sudah luntur dari nilai-nilai luhur manusia Indonesia yang terkenal dengan adat sopan santun dan ramah tamahnya.

Pengaruh teknologi seperti tayangan-tayangan yang ada di televisi yang jauh dari norma-norma agama akan ditiru oleh para pelajar sehingga membawa suatu perubahan yang berdampak pada kenakalan pelajar. Hal ini sejalan dengan pendapat More (dalam Narwoko, 2006) bahwa perubahan sosial sebagai suatu perubahan yang penting dalam struktur sosial, pola-pola perilaku dan sistem interaksi sosial termasuk di dalamnya perubahan norma, nilai dan fenomena kultural. Dengan munculnya teknologi seperti televisi yang menayangkan acara-acara hiburan yang menarik bahkan jauh dari norma-norma agama dan tanpa pendampingan orang tua yang menyebabkan remaja meniru perilaku di luar dari normayang berdampak pada perubahan pola perilaku yaitu kenakalan remaja di sekolah seperti tidak menghormati guru tetapi melakukan tindakan kekerasan terhadap guru.

Untuk itu maka peranan orang tua dalam keluarga sangat kuat untuk mengkontrol perilaku anaknya supaya tidak menyimpang.Terjadinya kekerasan dalam dunia pendidikan yaitu kenakalan remaja terhadap guru yang menjadi objek penderita/korban karena perilaku dari pelajar.Seorang pelajar dapat melakukan tindakan yang tindakan yang tidak pantas terhadap gurunya. Hal ini merupakan perilaku yang menyimpang yaitu pelajar melakukan tindakan kekerasan terhadap gurunya atau pelajar melakukan tindakan yang tidak pantas terhadap gurunya seperti kasus yang telah saya paparkan di bagian bab pendahuluan sehingga sangat dibutuhkan kontrol/pengendalian dari keluarga yaitu orang tua. Hal ini diperkuat dari teori kontrol oleh Hirschi (dalam Narwoko, 2006) bahwa penyimpangan dan bahkan kriminalitas atau pelaku kriminal, merupakan bukti kegagalan kelompok-kelompok sosial konvensional untuk mengikat individu agar tetap konform, seperti keluarga, sekolah, atau institusi pendidikan dan kelompok-kelompok dominan lainnya. Di dalam kontrol sosial internal ada empat unsur yaitu kasih sayang, tanggung jawab, keterlibatan dan kepercayaan/keyakinan.

Dari teori yang telah diuraikan di atas jika dikaitkan terhadap tulisan ini mengenai kekerasan dalam dunia pendidikan yaitu kenakalan pelajar terhadap guru maka sangat dibutuhkan adanya kontrol atau pengendalian dari keluarga dimana peranan orang tua sangat dominan dalam mengkontrol perilaku anak-anaknya dalam 
lingkungan sekolah maupun lingkungan tempat tinggal selain itu adanya kerjasama dan tanggung jawab antara orang tua dan guru serta kepala sekolah di sekolah dalam mengkontrol perilaku pelajar. Intinya seorang guru dalam mengajar di dalam kelas tidak hanya berfokus pada bagian kognitif saja tetapi bagian afektif dan psikomotorik maksudnya selain memberikan materi pelajaran, guru juga harus memberikan wejangan seputar pendidikan moral dengan cara menyisipkan di sela-sela materi pelajaran.Sebagai ujung terdepan dalam pendidikan anak, sekolah juga memiliki peran yang sangat vital.Kegiatan ektrakulikuler dalam pendidikan karakter dan pengembangan bakat serta minat yang dilaksanakan di sekolah juga harus menyisipkan pendidikan moral sehingga kenakalan pelajar tidak terjadi dalam dunia pendidikan.

\section{KESIMPULAN}

1. Kenakalan pelajar tidak terlepas dari pengaruh pola relasi subjek - objek yang terbangun dalam ilmu pengetahuan.

2. Pola relasi tersebut berakar pada perkara tidak objektivitas sistem pendidikan di Indonesia yaitu mengenai prinsip, tujuan, organisasi sosial, kurikulum, metode mengajar, evaluasi, anak didik, pendidik, fasilitas dan pembiayaan.

3. Pendidikan moral sangat penting dalam dunia pendidikan. Pendidikan moral adalah pendidikan yang bukan mengajarkan tentang akademik namun non akademik khususnya tentang sikap dan bagaimana perilaku sehari-hari yang baik.

4. Pendidikan moral sudah dikalahkan oleh pendidikan yang lainnya, waktu di sekolah habis untuk mengejar nilai akademik. Murid-murid dipaksa belajar agar nilainya pada saat ujian nanti membaik dan bisa mengharumkan nama dimana dia bersekolah. Guru lupa ada pelajaran yang lebih penting dari semua itu yaitu pendidikan moral.

5. Kehancuran dalam dunia pendidikan terjadi karena nilai akademik memburuk namun karena moral yang hancur.

6. Pendidikan nilai merupakan suatu upaya pembelajaran kepada peserta didik untuk memahami dan mengenal, menanamkan dan melestarikan, menyerap dan merealisasikan nilai-nilai luhur dalam kehidupan manusia yang berhubungan dengan kebenaran, kebaikan dan keindahan dalam pembiasaan bertindak yang konsisten dengan tuntutan nilai. 
7. Keluarga sebagai lingkungan yang pertama membentuk sifat, watak, dan tabiat manusia sudah sepantasnyalah memiliki peranan yang sangat besar dalam pelaksanaan pendidikan nilai terhadap anak.

8. Kenyataan dimasyarakat banyak peran orang tua diserahkan dalam mendidik anakanaknya ke orang lain atau para asisten rumah tangga, sudah barang tentu anak-anak tersebut memiliki sifat atau tabiat yang akan jauh berbeda dengan tabiat orang tuanya dan anak akan cenderung mengikuti apa yang ia lihat, yang menyenangkan dirinya tanpa disadari oleh baik buruk, benar salah, wajar tidak wajar, pantas tidak pantas, boleh tidak semua itu akan dilabraknya.

9. Keluarga dan kehidupannya tidak boleh disepelkan dan diabaikan. Padahal kecenderungan sekarang akibat kebutuhan material yang kian memuncak, banyak ibu dan bapak bekeja dan menyerahkan masalah hidup anaknya kepada asisten rumah tangga atau "orang bayaran" sehingga hamper segala urusan pendidikan sepenuhnya diandalkan kepada sekolah dan celakanya di sekolah masalah afektual, nilai moral hampir-hampir tidak tersentuh.

10. Pengaruh teknologi juga seperti tayangan-tayangan yang ada di televisi yang jauh dari norma-norma agama akan ditiru oleh para pelajar sehingga membawa suatu perubahan yang berdampak kepada kenakalan pelajar.

11. Kenakalan pelajar merupakan perilaku yang menyimpang dimana pelajar melakukan tindakan kekerasan seperti pelajar mem-bully guru. Untuk itu diperlukan suatu kontrol / pengendalian dari keluarga yaitu orang tua, pihak sekolah dan komunitas ekstrakulikulerhal ini sejalan dengan teori kontrol oleh Hirski bahwa penyimpangan dan bahkan kriminalitas atau pelaku kriminal merupakan bukti kegagalan kelompok-kelompok sosial konvensional untuk mengikat individu akan tetap konfrom seperti keluarga, sekolah atau kelompok-kelompok dominan lainnya.

\section{DAFTAR PUSTAKA}

Ahmadi, Abu. 1991. Sosiologi Pendidikan. Jakarta: Rineka Cipta.

Ari, Gunawan. 2010. Sosiologi Pendidikan. Jakarta : Rineka Cipta.

Ahmad, Tafsir. 2012. Filsafat Pendidikan Islam (Integrasi Jasmani, Rohani dan Kalbu Memanusiakan Manusia). Bandung: Remaja Rosdakarya. 
Alexander Aur. Relasi Guru-Murid Dalam Pendidikan.http://id.beritasatu.com// 9 Februari 2018.

Asmani mamur, Jamal. 2012. Kiat Mengatasi Kenakalan Remaja Di Sekolah. Jakarta: Buku Biru.

Binti, Maunah. 2016. Sosiologi Pendidikan. Yogyakarta: Kalimedia.

Djaali. 2008. Psikologi Pendidikan. Jakarta: Bumi Aksara.

Faiq Hidayat. Viral Guru.https://new.detik.com/13 November 2018.

Idi, Abdullah. 2011. Sosiologi Pendidikan (Individu, Masyarakat Dan Pendidikan). Jakarta: RajaGrafindo Persada.

Jefri.Pentingnya pendidikan Moral Pada Dunia Pendidikan "Zaman Now".https://www.kompasiana.com/5 Januari 2018.

Lisye Sri Rahayu.Mengapa Ada Siswa Brutal Kepada Guru.https://republika.co.id/ 18 Maret 2019.

Narwoko, Dwi\& Suyanto, Bagong. 2006. Sosiologi: Teks Pengantar \& Terapan. Jakarta: Kencana Prenada.

Nasution, S. 2011. Sosiologi Pendidikan. Jakarta: Bumi Aksara.

Sudarsono. 2008. Kenakalan Remaja. Jakarta: Rineka cipta.

Perilaku Kekerasan Di Sekolah Akibat Minimnya Budaya Literasi. https://daerah.sindonews.com/ 12 Februari 2018. 